UDC 37.014.523(497.11)"2000/...”; 371.3::2(497.11)"2000/...”; 316.644-053.6:2(497.11)"20"

CERIF: S140

\author{
Sima Avramović, $\mathrm{PhD}^{*}$
}

\title{
RELIGIOUS EDUCATION IN PUBLIC SCHOOLS AND RELIGIOUS IDENTITY IN POST-COMMUNIST SERBIA
}

The author analyses types of religious education in European and Serbian state-run schools searching for an innovative approach to existing classifications. He suggests four criteria to differ and categorize types of religious education in public schools, claiming that the actual taxonomy is often insufficient, inconsistent or perplexed (having usually been based upon one or two elements). He proposes categorization which encompasses point of view and interests of tax payers, of the politics, of the pupils and of the religious teachers. More criteria could lead to a better assessment of particular system of religious education. He also suggests that, apart from usual categorization in confessional and non-confessional religious education, it would be useful to introduce categories like "mostly confessional" and "mostly non-confessional", as clear-cut models are very rare. In addition to this he offers arguments why "cognitive" type of religious education would be more proper label instead of "non-confessional".

Further on the author examines controversies, disputes and manner of reintroduction of religious instruction in Serbian legislation after the fall of the communist regime in 2000 and presents the current situation, including very recent changes considering curricula. He points to some very distinctive features of religious education model in Serbia which could be of interest in comparative perspective, particularly in the time when many states in Europe tend to improve their religious education system. Finally, he points to importance of religious education in building religious identity of young generations in post-communist countries, and differs two types of religious identity - perceptive (intuitive) and cognitive (rational). He concludes that "educating into religion" has to exist for some time in post-communist countries due to historical circumstances (within more or less confessional model). Additionally, he finds that it should be only gradually transformed into "edu-

* Professor, University of Belgrade Faculty of Law, sima@ius.bg.ac.rs. The paper is mostly instigated by my lecture given at the Lumsa University Faculty of Law in Palermo in April 2016. I am very grateful to Italian colleagues for important and valuable imputes during the discussion. 
cating about religion" and "education from religion" pattern, fostering cognitive religious identity to strengthen parallel with the perceptive one.

Key words: Secularity. - Toledo Guiding Principles. - Models of Religious Education. - Intuitive Religious Identity. - Cognitive Religious Identity.

\section{INTRODUCTION}

Religious education/instruction in public schools is an important element of the right to religious freedom. ${ }^{1}$ Many international documents and declarations provide for obligation of the states to ensure the religious and moral education of the children in conformity with their parents'convictions. It includes right to obtain proper instruction in religion in proper age and place, offered by proper educators. But that objective is shaped quite differently in various legal systems. All member countries of the EU (except Slovenia, but including France in AlsaceLorraine $^{2}$ ) recognize and respect importance of religious education (RE) in public schools and organize it in some form. ${ }^{3} \mathrm{RE}$ is overwhelmingly

1 I do not follow consequently English terminological distinction where the term religious instruction refers usually to teaching of a particular religion (confessional type), while religious education implies mostly teaching about religions in general (cognitive approach). This terminological distinction is quite tricky, particularly as many models or sub-models of religious education exist in between the two mentioned. Also, it may reflect a kind of prejudice that within the confessional courses of religious instruction there is no room for teaching about other religions and vice versa. Therefore, I prefer to use terms religious instruction and religious education as synonyms.

2 In other parts of France there is no RE in public schools in a strict sense, although chaplaincy can be established in secondary schools upon request of pupils or parents. In coordination with the school authorities the chaplain (aumônier) can give classes in religion in the school premises, but not in the school time nor within the regular school curriculum. Therefore, it is not quite accurate to say that there is no RE in public schools in France as a consequence of the secularity principle. Existence of regular religious instruction in the part of state territory, as it is organized in Alsace-Lorraine, clearly demonstrates that even in French legal lenses, presence of RE in public schools does not violate constitutional principle of laïcité and separation of church and state.

On history and tendencies in RE in France, see particularly: J. P. Willaime, "Teaching Religious Issues in French Public Schools. From Abstentionist Laïcité to a Return of Religion to Public Education", Religion and Education in Europe (eds. R. Jackson et allia), Münster - New York - München - Berlin 2007a, 87-102 and F. Messner, "Religion et éducation en France", Religion in Public Education - La religion dans l'éducation publique (ed. G. Robbers), Trier 2011, 155-166.

3 Schreiner stresses that "Religious education is part of the curriculum in most of the European states". He mentions only France, Slovenia and Macedonia as countries with no RE (although Montenegro and Albania should also be added). See: P. Schreiner, "Situation and Current Developments of Religious Education in Europe", Religious Education in a Plural, Secularised Society. A Paradigm Shift (eds. L. Franken, P. Loobuyck), Münster - New York - München - Berlin 2011, 19. 
regulated not only at the international level but also in the national legislations and discussed in public. The majority of European states do not deny value and importance of RE in state-run schools. Only its nature, type and goals can be a matter of dispute. Role of RE particularly in primary and in secondary schools, regardless of being public or private, can be of vital importance for the formation of young people, their attitude towards their own religion and faith of the others, but also to foster better understanding of religious diversity and of the society as a whole. Of course, other elements also affect religious identity, particularly ethnicity. It is well observed that national identity is strongly connected to prevailing religion, such as Lutheranism in Denmark, Catholicism in Italy, Orthodoxy in Greece, etc. ${ }^{4}$ Parental responsibility is also crucial in formation of religious profile of their children depending on their attitude towards their own and other religions and beliefs. Religious instruction in schools is also an influential factor in religious identity building, developing positive social attitude and avoiding religious isolation, hatred and abuse of religious feelings. Some studies have shown that a positive correlation exists between RE and democratic conduct - the lesser the degree of religious education, the greater the potential for religious differences to be politically instrumentalized. ${ }^{5}$ In brief, RE in public schools is of great

4 J. P. Willaime, "Different Models for Religion and Education in Europe", Religion and Education in Europe (eds. Robert Jackson et allia), Münster - New York München - Berlin 2007b, 57.

Confessional-national symbiosis is particularly firm in Balkan countries. This is also true in case of Serbia where about $85 \%$ of the population declared as Orthodox Christians. According to the census of 2011, out of total number of 7,186.862 inhabitants, religious structure of Serbia is as follows:

$\begin{array}{llll}\text { Orthodox Christians } & 6,079.396 & - & 84,59 \\ \text { Catholics } & 356.957 & - & 4,96 \\ \text { Muslims } & 222.828 & - & 3,10 \\ \text { Protestants } & 71.284 & - & 0,99 \\ \text { Other Christian religions } & 3.211 & - & 0,04 \\ \text { Jews } & 578 & - & 0,01 \\ \text { Oriental cults } & 1.237 & - & 0,02 \\ \text { Other religions } & 1.776 & - & 0,02 \\ \text { Agnostics } & 4.010 & - & 0,06 \\ \text { Atheists } & 80.053 & - & 1,11 \\ \text { Unanswered } & 220.735 & - & 3,07 \\ \text { Unknown } & 99.714 & - & 1,38\end{array}$

Source: http://webrzs.stat.gov.rs/WebSite/Public/PublicationView.aspx? $p$ Key $=41 \& p$ Level $=1 \&$ pubType $=2 \&$ pubKey $=1586$.

5 Very convincing is the research by A. Hasenclever, "Geteilte Werte - Gemeinsamer Frieden? Überlegungen zu zivilisierenden Kraft von Religionen und Glaubensgemeinschaften", Friedenspolitik: Etische Grundlagen internationaler Beziehungen (eds. H. 
significance for the society due to its impact on democratic conduct of the young generations.

The goal of this text is to reveal the process of re-introduction of religious instruction in public schools in Serbia, its peculiarities and place within the existing models of RE organization, but also how it affects religious identity of youth after many decades of official atheist dogma. It is still a matter of dispute if religious instruction in state-run schools harms the principle of secularity and, in the last instance, if it has positive or negative impact on the whole society. Those two topics are quite hot and controversial in the public discourse of Serbia, but academic elaboration, particularly in foreign languages, is quite scarce. ${ }^{6}$ The aim of this article is also to point to strengths and weaknesses of religious instruction in Serbia and to explore how much it can, with some modifications, contribute fostering formation of tolerant religious identity of the young postatheist generations. Now when the society is faced with strong revival of religion after its long lasting suppression it is important to keep in mind the importance of the relationship between religion and identity. ${ }^{7}$ Also, some unique solutions applied in Serbian legislation might be useful for comparative research. Many countries in Europe are still seeking for the best possible approach in organizing RE in public schools and it is quite suitable domain for legal transplants. ${ }^{8}$

Küng, D. Senghaas), München 2003, 204. See also: W. Weisse, "The European Research Project on Rerligion and Education REDCo. An Introduction", Religion and Education in Europe (eds. R. Jackson et allia), 2007, 9.

6 Indeed, there are no many academic contributions on RE in Serbia, particularly in the last ten years years. One should firstly observe (at least at the Internet) two early texts written in the time when religious instruction was reintroduced in Serbia: B. Aleksov, "Religious Education in Serbia", Religion, State \& Society, 4/2004, 340-361 and Z. Kuburic, M. Vukomanovic, "Religious education: the case of Serbia", Sociologija, 3/2005, 230-253. Those contributions depict hot debate in Serbia about introduction of religious instruction in state-run schools. More recent analytic papers are mainly missing. There is an interesting text by D. Kaurin, W. J. Morgan, "Orthodoxy and Education in Post-Socialist Serbia, A Comment", Journal of Religion and Society 15/2013, 1-7, but it is more of a short observation (as noted in the title) than elaboration of the issue. The most comprehensive book in Serbian is a very detailed collection of documents about the introduction of RE in Serbia, M. D. Jankovic, "Vracanje verske nastave u obrazovni sistem Srbije" [Return of Religious Instruction in Educational System of Serbia], Novi Sad 2015, 550.

7 More in Steward Harrison Oppong, "Religion and Identity", American international Journal of Contemporary Research, 3, 6/2013.

8 Serbian model of RE is basically influenced by German solutions (German concept of cooperative separation of the state and Church is in general prevailing in Serbian legislation). Of course, in issues of religious instruction in public schools historical, ethnic, societal, political, religious demography and many other peculiarities play an important role in adapting models borrowed from the donor legal system, as contextual approach to $\mathrm{RE}$ is unavoidable. 
However, the issue in Serbia is not only what would be the best model of religious instruction in state-run schools. There are still more extreme voices, as well as in some other post-communist countries, ${ }^{9} \mathrm{im}$ posing crucial questions: is religious instruction still necessary in public schools curricula today and does it contradict to the principle of state neutrality ${ }^{10}$ Some answers are already well elaborated in the Toledo Guiding Principles on Teaching about Religions and Beliefs in Public Schools prepared by the OSCE Office for Democratic Institutions and Human Rights, more precisely by its Advisory Council of Experts on Freedom of Religion or Belief in 2007. ${ }^{11}$ The document assumes that religious instruction in public schools is legitimate activity which does not challenge the secularity principle. It also stresses that teaching about religion would be a desiring goal which can contribute to better understanding of different religions in multicultural and changing Europe. Toledo Guiding Principles do not pretend to impose changes in different national legislations of RE in public schools and does not foster any model. It only traces a possible preferable road and tools that would contribute to enhance religious freedom and promote good practices in RE in the future.

After the fall of the Berlin Wall and emergence of the post secular wave, already in 1990s or in early 2000s many ex-communist/socialist Eastern European countries (Poland, Bulgaria, Romania, Slovakia, Latvia, Lithuania, etc.), introduced mostly confessional RE in state-run schools when they abandoned harsh ideological heritage. Some countries of the former Eastern Block have preferred non-confessional RE in public schools (Estonia), while the Check Republic and Hungary do not have $\mathrm{RE}$ within the regular school curricula but churches and religious communities can organize religious classes in schools within the school hours. ${ }^{12}$ Several countries of ex-Yugoslavia did not introduce RE in pub-

9 P. Valk, "Religious Education in Estonia", Religion and Education in Europe (eds. Robert Jackson et allia), Münster - New York - München - Berlin 2007, 171 illustrates that harsh debates on religious instruction in a post-communist country affect nearly all strata of the society.

10 It is not only a political but a doctrinal, academic issue. See three different views in the recent book Religious Education in a Plural, Secularised Society. A Paradigm Shift (eds. L. Franken, P. Loobuyck), Waxmann, Münster - New York - München - Berlin 2011, 117-168 (contributions by F. Schweitzer, T. Jensen and P. Cliteur).

11 http://www.osce.org/odihr/29154, last visited 5 October 2016.

12 In Hungary RE in public schools is delivered by churches and religious communities, not by the school. The religious instruction is not a part of school curriculum, the teacher is not a member of the school staff, grades are not given in the school report, the churches decide freely on the content of religious instructions, teachers are church employments, but the state provides funding for the churches. The school has only to obtain appropriate time for classes, B. Schanda, "Religious education in Hungary", The Routledge International Handbook of Religious Education (eds. D. H. Davis, E. Miroshnikova), London - New York 2013, 141. See also: B. Schanda, Legislation on Church- 
lic schools until today (Slovenia, Monte Negro, and FYR of Macedonia). ${ }^{13}$ On the contrary, Croatia, Serbia and Republic of Srpska established confessional religious instruction in public schools, while in the Federation of Bosnia and Herzegovina RE was also established in different forms in many cantons.

Restoration of religious instruction in public schools took place in Serbia about a decade later than in other countries with similar political and ideological background. It was mostly consequence of tragic events connected with the dissolution of Yugoslavia and continuation of basically communist policy by the Milosevic regime, who rejected all initiatives for introduction of RE. After the democratic changes in 2000 and fall of Milosevic, religious instruction in public schools was quite quickly introduced, along with general rapid revival of religion. ${ }^{14}$. It provoked a very heated and divisive debate in public discourse. ${ }^{15}$ The question was not what form of RE should be organized but whether it should be installed in the public schools curricula at all. After two "religious cases" at

State Relations in Hungary, Budapest 2002, 22-23. The Czech Republic has a similar system, J. R. Tretera, Z. Horák, "Religion in Public Education in the Czech Republic", Religion in Public Education - La religion dans l'éducation publique (ed. G. Robbers), Trier 2011, 105.

13 Albania also does not have RE in public schools yet, K. Loloçi, "Albania”, in: Encyclopedia of Law and Religion, I-V (eds. G. Robbers, W. C. Durham), Leiden - Boston 2016, IV, 7. It is significant that many South-Eastern former communist countries are still quite attached to inherited atheist tradition of avoiding religious instruction in public schools.

14 More about the political background and different opinion within the Government of the Republic of Serbia in that time, see A. Prascevic, "The Process of Religious Education in Public Schools of Republic of Serbia 2001-2011", http://www.pravoslavie. ru/english/51724.htm, last visited 5 October 2016.

15 Among many discussions in media, at the Constitutional Court, etc. an academic debate between two professors of the University of Belgrade Faculty of Law also had effect: M. Draskic, "Pravo deteta na slobodu veroispovesti u skoli", Anali Pravnog fakulteta u Beogradu ["Right of children to religious freedom in schools", Annals of the Faculty of Law in Belgrade], 1-4/2001, 511-523; S. Avramovic, "Pravo na versku nastavu u našem i uporednom pravu", Anali Pravnog fakulteta u Beogadu ["Right to religious instruction in our and comparative law", Annals of the Faculty of Law in Belgrade], 1/2005, 46-64; M. Draskic, "O veronauci u državnim školama, drugi put", Anali Pravnog Fakulteta u Beogradu ["On religious instruction in public schools, the second time", Annals of the Faculty of Law in Belgrade], 1/2006, 135-151; S. Avramovic, "Ustavnost verske nastave u državnim školama - res iudicata", Anali Pravnog fakulteta u Beogradu ["Constitutionality of religious instruction in public schools - res iudicata", Annals of the Faculty of Law in Belgrade], 2/2006, 251-257 (all in Serbian); S. Avramovic, "Right to Religious Instruction in Public Schools", Annals of the Faculty of Law in Belgrade 3/2006, 4-17 (response to M. Draskic in English).

See also S. Avramovic, "Church and State in Serbia", in: Law and Religion in PostCommunist Europe (eds. S. Ferrari, W. C. Durham), Leuven - Paris - Dudley, MA 2003, 295-310; S. Avramovic, "Serbia", in: Religion and the Secular State: National Reports (eds. W. C. Durham, J. Martinez-Torron), Madrid 2015, 599-613. 
the Constitutional Court of Serbia (in 2003 and 2013), ${ }^{16}$ it seemed that $\mathrm{RE}$ has founded its stable place. But, religious instruction is still vulnerable and is often challenged in legal, political, educational, social, psychological, and many other contexts. In 2016 Minister of Education of Serbia proposed to merge religious instruction with the alternative subject (in Serbia called "Civic education"). He did not claim that existence of $\mathrm{RE}$ in public schools is unnecessary or unconstitutional but defended his proposal by overloaded school curricula. It was a new opportunity for excited public dispute over existence of RE in public schools.

All those challenges have affected the Serbian pattern of religious instruction in public schools to become more receptive, flexible, specific, and interesting in comparative perspective. Different impacts, historical and political, educational and legislative, have shaped quite specific type of RE in Serbian public schools.

\section{MODELS OF RELIGIOUS EDUCATION IN PUBLIC SCHOOLS}

There is a variety of criteria to categorize existing types of RE in public schools and quite diverse solutions in different jurisdictions. Importance of various criteria is not the same and consequently there are varied classifications in the literature. Some authors take only one, while others are combining and perplexing different criteria. Several classifications are therefore a bit confusing. ${ }^{17}$ A recent book on RE in contemporary Europe differs denominational model, absence of RE, multi-faith pattern, non-denominational type, mixed model (denominational and non-denominational, compulsive and non-compulsive) and non-denominational integrative mod-

16 Constitutional Court of Serbia, IU-214/2002, ruling of November 4, 2003 (Official Gazette of the Republic of Serbia, No. 119/2003) and IUz-455/2011, ruling of January 13, 2013 (Official Gazette of the Republic of Serbia, No. 23/2013). On the contrary, Supreme Court of Macedonia rejected in 2009 the Law on Schools of 2007, which provided establishing RE in public schools, on the basis that it violates the principle of separation of the state and church.

17 P. Schreiner, "Religious education in the European context", in: Crossings and Crosses: Borders, Educations, and Religions in Northern Europe (eds. J. Berglund, T. Lundén, P. Strandbrink), Boston - Berlin 2015, 145 differs three basic types of religious instructions depending on who organizes RE. The first is teaching by religious communities with exclusive responsibility for RE (denominational/ confessional/ catechetical; mainly a voluntary subject, e.g. in Poland, Ireland, Italy). The second is teaching organized in collaboration between state authorities and religious communities (denominational/confessional/non-confessional; voluntary and/or obligatory subject, e.g. in Austria, Belgium, England, Germany, Greece, Hungary, Russia, Spain, some parts of Switzerland). The third is teaching organized exclusively by state authorities (non-confessional, religious studies; obligatory subject, e.g. Denmark, Estonia, Finland, Norway, Sweden, some parts of Switzerland). The author adds that the fourth "type" is the one with no RE. 
el. ${ }^{18}$ This perplexing example of categorization attests need to define and rank criteria clearly in order to achieve proper outcome.

J-P. Williame proposes the most frequent and acceptable classifications, following approach of S. Ferrari. It recognises three categories: states with no RE, confessional religious instruction and non-confessional RE. ${ }^{19}$ Basically, there is only one criterion applied: essence/content of RE (confessional or non-confessional). Content of RE is certainly among the most important elements, but it is not sufficient to describe other vital features of RE models. Variety of RE types should be followed by more diversified criteria and classifications. In order to describe some pattern of RE more comprehensively, it should be followed by at least few important criteria or, better to say, elements that shape RE in particular country. Four of them seem to be central from different points of view.

The first one should be perceived from the point of view and interest of tax payers. They consider whether the state undertakes burden of financing RE in public schools or not, whether the state performs it alone or shares the costs with beneficiaries, how many churches and religious communities have that privilege, etc. ${ }^{20}$

Secondly, from political and educational standpoint, the most important issue is its content - is RE profiled as denominational/confessional or non-denominational/non-confessional, cognitive subject? ${ }^{21}$ What should be the prevailing essence of teaching, what are the most important

18 Religious Education in a Plural, Secularised Society. A Paradigm Shift (eds. L. Franken, P. Loobuyck), Münster-New York-München-Berlin 2011, 10.

19 J-P. Williame, 60. He reffers mostly to the article of S. Ferrari, "L'enseignement des religions en Europe: un aperçu juridique", in: Des maîtres et des dieux. Ecoles et religions en Europe (eds. J-P. Willaime, S. Mathieau), Paris - Berlin 2005, 31. Silvio Ferrari, "Religious education in the European Union", in: The Routledge International Handbook of Religious Education (eds. D. H. Davis, E. Miroshnikova), London - New York 2013, 100 has recently modified terminology a bit, but basicaly kept the same classification. He labels the second model as "non-denominational" teaching (instead of "non-confessional") but the essence is the same.

20 It is not always possible to make clear classification, which will fit completely to all types of RE in all countries, even when more diversified criteria are applied. For example, if the criterion is who pays costs of RE in public schools (the state or churches and religious communities), Serbia can not be easily classified in one or another type. Namely, RE in state-run schools is funded by the state for the seven traditional religions only. But, other churches and religious communities are free to organize RE on their own expenses, while the school is obliged to obtain premises (within the general limit of the minimum number of pupils). Therefore, sometimes classification should take into account prevalent characteristic of RE features in each country. Consequently, in case of Serbia, religious instruction in public schools is mostly, but not exclusively, the state paid effort.

21 However, there are many non-confessional approaches: combination with confessional RE, inter-confessional type, multi-confessional pattern, cultural or historical approach, etc. 
goals, objectives and educational outcomes of RE in public schools those are controversial political issues par excellence.

Thirdly, pupils perspective is mostly focused on question whether $\mathrm{RE}$ in public schools is a mandatory, elective/alternative or optional subject. From their point of view main issue is also whether the grade in RE is evaluated within the school system and whether it affects general average grade. Right to opt out completely or right to alter RE with the alternative subject is also important for the pupils as it may contribute to their mobility, enabling them to combine at some point RE and ethics, civic education, etc.

Fourthly, it is important to observe RE in public schools from the stance of religious teachers. Their legal standing may differ very much in different countries depending on who is in charge to authorise their position (the state, churches and religious communities or they do it cooperatively). The issue is whether they have a permanent post, are they employees of churches and religious communities or of the state, etc. Position of religious teachers is vital for the character and quality of RE in public schools. It is therefore also a significant criteria in defining types of RE.

Those are not the only criteria to be perceived in creating classifications of RE models. However, they are central in shaping the character of RE in the school system and society. For that reason it is not enough to seize only one or two criteria for a valid evaluation of RE pattern in particular countries.

2.1. In financing most countries incline towards state-paid religious instruction in public schools. It should mean that the state takes economic burden about preparing curricula, teachers' salaries, preparing and printing reading materials, etc. However, in many instances the state remunerate costs even when the churches and religious communities decisively affect curricula, appointment of the teachers, content of reading materials, etc. $^{22}$

The next problem connected with financing is whether the state is disbursing costs of religious instructions for all Churches, religions and denominations or only for some of them. It is a very delicate issue of equality and discrimination, on the one hand, but also of rational and effective conduct of the state, on the other. The matter is whether the state is obliged to organize and pay teachers and other costs for RE for every single religious denomination, regardless of how many followers it has. Selective approach is vulnerable by itself, particularly as choice of privileged churches and religious communities is mostly based upon historical

22 Austria, Spain, Portugal, Malta, Poland, Greece, Cyprus, Belgium, Czech Republic, etc. 
(long presence of the religion in the country - how long?) or statistical data (number of followers - how big should it be?). Also, which number of pupils who opt for RE imposes obligation to the state to organize and pay RE in public schools for them? The answer depends upon financial capabilities of the country, social sensitiveness, perception of rational expenditures of the state budget, etc. ${ }^{23}$

Issue of financing is often used and abused in discussions about RE existence in public schools due to its unavoidable selectiveness. Parents who are believers expect that they have right as tax payers to rely upon the state to educate properly their children in religion in conformity with their convictions. The state has a duty to assist parents on their children's education in general, as well as in adequate religious upbringing, but then it faces the issue of fiscal rationality.

2.2. The second issue is even more complicated and delicate: which content is offered to the pupils through RE classes? Most countries still incline predominantly to confessional approach, such as Germany, Austria, Italy, Spain, Greece, Belgium, Denmark (in primary and first classes of secondary schools), Luxembourg, Ireland, Poland, Slovakia, Bulgaria, Romania, Croatia, Serbia, Republic of Srpska, etc. However, in many countries pupils are actually offered to learn a bit or a lot about other religions. There is a general tendency to shift RE towards more cognitive contents, with or without legal provisions and curricula.

The other most frequent pattern is non-confessional, non-denominational, cognitive (informative). That model has been usually introduced through legislative reforms (although it is sometimes consequence of internal and factual development). It mostly affects curricula of the higher classes (Great Britain, Norway, Finland,-- upper classes of secondary schools). In some countries cognitive approach can vary quite a lot, both in its content and in timing when it will be introduced in the curricula (Sweden, Denmark, Lithuania, Estonia). Teaching "about religion" can be oriented towards some group of religions (e.g. Christianity including all denominations, Orthodox culture as proposed in Russia at some point, ${ }^{24}$

23 Finland prescribes minimum of only 3 pupils who belong to non-registered churches and religious communities. In Germany the state is obliged to organize and pay classes (as religious education is regarded as a constitutional right) if the minimum number of interested pupils is 6 to 12. In the Czech Republic and Poland minimum number of pupils is 7, in Portugal 10, in Slovakia 12, in Estonia and Serbia 15, etc.

24 Russia has quite a fluid model. After the dissolution of USSR religious instruction was non-confessional or there was no RE, depending on regional or local regulations, F. Kozyrev, V. Fedorov, "Religion and Education in Russia, Historical Roots, Cultural Context and Recent Developments", Religion and Education in Europe (eds. R. Jackson et allia), Münster - New York - München - Berlin 2007, 133-158; E. G. Romanova, "Religious education in modern Russia", The Routledge International Handbook of Religious Education (eds. D. H. Davis, E. Miroshnikova), London - New York 2013, $287-$ 
etc.), towards selected types of the most important religions (when the issue of criteria arises) or about all existing religions in the world. Also it can focus teaching about comparative history of religion/s, philosophy of religion/s, institutions of religion/s, religious doctrines, religious knowledge, etc. This is why I prefer to label the non-confessional model as cognitive (informaive).

Therefore, strict distinction into confessional and non-confessional type of RE can not fit completely well inthe legislative reality in many countries. Basically, there are not so many clear cuts, binary models of $\mathrm{RE}$ in state-run schools considering content of the subject. Due to gradual informal or formal involvement of multi-confessional and cognitive elements into teaching of confessional religion, it would be useful to add into the existing black and white classification at least two, more flexible types: mostly confessional and mostly cognitive. ${ }^{25}$ It could help to describe better many varied systems and different approaches. Also, it could probably make more visible the fact that most of existing RE patterns are essentially mixed in content, and that the tendency of convergence is quite current. ${ }^{26}$ Those assorted RE models are now probably dominant or at least they are tending to become dominant.

2.3. The most important issue for the pupils is whether religious instruction is a regular subject for all or not. The issue has its pedagogical, but also legal, societal, political and many other aspects. In some legal systems RE in state-run schools is a mandatory, obligatory, required subject within the regular curriculum, without possibility to opt out. This model might be criticized in terms of right to equality and non-discrimination, violation of children's rights, etc. ${ }^{27}$ The issue is thoroughly discussed during past decades, but nevertheless compulsory RE is often a regular subject (regardless of its content - confessional or cognitive).

294. Since 2012 public schools in Russia have started to teach "Fundamentals of religious cultures" which includes four religions - Orthodoxy, Islam, Buddhism, and Judaism. Pupils can choose one of these four religions, a survey of world religions or take a secular course in ethics. See E. Lisovskaya, "Religious Education in Russia: Inter-Faith Harmony or Neo-Imperial Toleration?", Cogitatio, Social Inclusion 4, 2/2016, 117-132.

25 Term "cognitive" underlines different kinds of knowledge that could be included in non-confessional courses (it usually includes knowledge and doctrine of other religions, but also cultural facts about the pupil's own religion). In the same way confessional approach does not exclude non-confessional elements. This is the good reason to favor the notions like mostly confessional and mostly cognitive.

26 J-P. Willaime, 2007a, 65; P. Schreiner, 23.

27 General Comment adopted by the Human rights Committee of the International Covenant on Civil and Political Rights, No. 22 (48) (art. 18) states: "The Committee notes that public education that includes instruction in a particular religion or belief is inconsistent with article 18 (4) unless provision is made for non-discriminatory exemptions or alternatives that would accommodate the wishes of parents and guardians". 
Mandatory type of RE is frequent in the jurisdictions which had experienced state religion and the State-Church model. Although its essence was at first mostly confessional, some countries switched to mostly nonconfessional or multi-confessional contents (Great Britain, Denmark, Finland, ${ }^{28}$ Sweden, ${ }^{29}$ Norway $\left.^{30}\right)$. On the other side RE in Greece, ${ }^{31} \mathrm{Cy}$ prus and Malta is also mandatory, but it is strictly confessional. Some countries belonging to other models of the state-church relationships are also favoring mandatory and confessional RE in public schools. This is the case in Austria, ${ }^{32}$ in two entities of Bosnia and Herzegovina - in Republic of Srpska, in some cantons of the Federation of Bosnia and Herzegovina, etc.

28 It is usually stated that in Finland RE is mandatory but non-confessional subject. However, pupils both of elementary and secondary schools attend classes according to their religion (about 92\% Evangelical-Lutheran RE, 1,4\% in Orthodox, 1,5\% in Islam, $0,5 \%$ in other religions, $4 \%$ Ethics). Those who do not belong to any religion have classes in Ethics, http://www.suol.fi/index.php/uskonnonopetus-suomessa/religious-educationin-finland, last visited 5 October 2016. It contradicts in a way to qualification that the subject is non-confessional. It is basically rather multi-confessional and cognitive as pupils still receive elementary information primarily in their own religion. More about RE in Sweden, Norway, Denmark and Finland: V. Llorent-Bedmar, V. Cobano-Delgado, "The Teaching of Religious Education in Public Schools in the Nordic Countries of Europe", Review of European Studies 6, 4/2014, 50-57.

29 Although State and Church were formaly separated in 2000, Church of Sweden kept many privileges that were granted to it by the state. As for religious instruction, confessional education is generally offered in the schools which receive a subsidy from the private sector, often organizations of a religious nature. It is also possibile to receive confessional RE in public schools, when they also receive State subsidies, V. LlorentBedmar, V. Cobano-Delgado, 55.

30 Church was separated from the State by constitutional amendment of 2012 but the Church of Norway remains state-funded, where bishops and priests are still civil servants, as well as RE remained mandatory subject paid by the state.

31 It is a very long tradition in Greece that RE is a mandatory subject both in public and private schools. The right to opt out is recognized for non-Orthodox pupils. The content of the subject is strongly influenced by Orthodox theology. Participation at religious services is practiced usually once a month. Daily common prayer must necessarily be made, every day before the start of the course, at a joint gathering of students and teachers in the schoolyard, see: N. Ch. Magioros, "Religion in Public Education - Report on Greece", Religion in Public Education - La religion dans l'éducation publique (ed. Gerhard Robbers), Trier 2011, 195-216.

32 Religious instruction in public schools is still regulated in Austria by the law of 1949 (Religionsunterrichtsgesetz) and its status seems quite stable. It is an obligatory subject for all pupils who are members of a legally recognized church or religious community in all primary schools. Churches and religious communities are responsible for organization and curriculum of the religious instruction but the state pays teachers, manuels, etc. More in S. Hammer, J. Franck, "Religion in Public Education - Report on Austria", Religion in Public Education - La religion dans l'éducation publique (ed. G. Robbers), Trier 2011, 39-62. 
$\mathrm{RE}$ in public schools is frequently offered to pupils as compulsory (mandatory) but optional subject with an alternative. Alternative subjects are usually ethics or moral or some other peculiar subject, like "Civic education" in Serbia. The model does not attract so many objections considering discrimination and violation of constitutional principles. Pupils/ parents have an alternative, freedom of choice between the two topics. So the claim that RE is imposed to the pupils/parents contrary to their wish or conviction is not operational. This model is wide spread - in Germany, Belgium, Luxembourg, Netherlands, Slovakia, Moldova, Latvia, some cantons in the Federation of Bosnia and Herzegovina, Croatia in secondary schools, schools for EU officers' children, etc.

In Portugal there is no alternative subject and pupils who want to opt out have free time during the lecture in RE. ${ }^{33}$ Similarly to this, Romania recognizes right of pupils to opt out, but an alternative subject is not provided. ${ }^{34}$ The last two examples are near to the system of completely elective courses. The difference is that pupils have to opt out (as the subject is mandatory), in the second case they simply choose RE or not, while in some countries their explicit request to have religious instruction is needed.

The third model includes completely elective, voluntary, non-compulsory subject. Pupils in public schools do not have to opt out as RE is not set forth in the regular curriculum. RE is offered as an elective course in Italy, Spain, Portugal (in high schools), Czech Republic, Poland, Hungary, Croatia in primary schools, Russia, Bulgaria, Ukraine, Estonia, Lithuania, etc.

Non-compulsory RE in public schools is particularly characteristic for many ex-communist countries, but it also exists in some countries with strong religious, particularly Catholic tradition (where religious instruction is either optional or elective). However, in Catholic countries majority of pupils often opt for religious instruction although they have no obligation (Italy, Spain, Portugal, Croatia in primary schools). Percentage of pupils who want to take religious instruction as an elective subject is quite high. Many of them opt for the Catholic religious instructions following tradition, due to expectations of the family, from personal religious feelings, for pragmatic reasons (counting of the average grade into the overall school grade record), etc. ${ }^{35}$ Namely, from the point of pupils,

33 A. Folque, "Religion in Public Portuguese Education", Religion in Public Education - La religion dans l'éducation publique (ed. G. Robbers), Trier 2011, 399-424.

34 E. P. Tăvală, "Religion and Public Education in Romania", Religion in Public Education - La religion dans l'éducation publique (ed. Gerhard Robbers), Trier 2011, 425-442.

35 During my lecture at the Lumsa University in Palermo in April 2016 nearly all present students (about 60), having been asked what was their personal choice during their previous schooling, declared that they did opt for RE. Having been asked why they opted 
grade in RE can also be an important motive to opt for that school subject, particularly if it affects the final school report. ${ }^{36}$ And to get the best grade in religious instructions is usually not a heavy task. Therefore it seems that grading policy can be a subtle motivation for pupils to attend $\mathrm{RE}$ in cases when it is an alternative or completely elective subject.

Finally, as already stressed, only a small number of countries have no religious instruction in public schools (Slovenia, FYR Macedonia, Montenegro, Albania, France with the exception in Alsace and Lorraine $^{37}$ ). However, Slovenia and Albania are slowly moving forward. A facultative non-confessional subject called "Religions and Ethics" was recently introduced in Slovenia (together with a compulsory subject "Civic and Patriotic Education and Ethics"), ${ }^{38}$ while during 2016 Albania is facing the Government initiative to include RE as a compulsory non-confessional course in secondary schools. RE convergence process in Europe is evidently in progress.

2.4. An important criterion to evaluate and qualify RE in public schools is connected to the status of religious teachers in terms of labor law, stability of their position and their motivation. There are basically three systems - when the church or religious community is completely in charge to select religious teachers for the position in the schools, when the choice of teachers is in hands of the state and when the state and religious institutions cooperate in their appointment and jointly regulate their

for religious instruction, most answers were that it was their wish, that they were influenced by the decision of their friends, that their parents made the choice for them, that they searched for a more profound knowledge in religion, etc.

36 Although religious instruction is elective, non-compulsory subject in Croatia, more than $85 \%$ of pupils attend it (grade in RE affects the average grade). In Italy about $91 \%$ of pupils choose classes in religious instruction; the grade is also counted in the evaluation of their final overall results, A. Ferrari, "La religion dans l'éducation publique - le cas Italien", in: Religion in Public Education - La religion dans l'éducation publique (ed. Gerhard Robbers), Trier 2011, 257-272. The same privilege has RE in public schools in Spain, where the grade received in RE is taken into account for promotion, J-P. Willaime, (2007b), 64. In Finland the grade in religious instruction also contributes to pupils' final average grade. On the contrary, in countries where religious instruction is a mandatory subject the grade (which is usually descriptive) most frequently does not influence the final school report (Austria, Serbia, etc.).

37 A gradual change regarding religion in France is quite evident, see more in J-P. Williame, (2007a), 87-102. He points that already since 1945 "militant" laïcité has gradually given way to "management" laïcité. This process is also described by two well known definitions. Famous French professor Jean Baubérot, in his programmatic book Vers un nouveau pacte laïque, Paris 1990, defined the process as "a pact for a new laïcité", while former French Minister of Education Régis Debray in 2002 (after the terrorist attack on September 11) defined it as a path "from a laïcité of ignorance to laïcité of understanding", J-P. Willaime, (2007b), 90, 93.

38 B. Ivanc, "Religion in Public Education - Slovenia", in: Religion in Public Education - La religion dans l'éducation publique (ed. G. Robbers), Trier 2011, 460. 
legal standing. Also it is relevant whether they are lay persons or priests, what their educational background is, if they are part of the school staff, if they are paid by the religious institutions or by the school (state), etc.

Personality and enthusiasm of the teachers strongly affect pupils' commitment to attend RE classes, particularly when they have a choice between two alternative subjects. Teacher's charisma is often a key factor for successful enrollment of pupils. An interesting recent research in Serbia manifests clearly that ambitious religious teachers are often more inovative than the official syllabi, and that they are introducing topics related with psychology, philosophy, literature and history, Biblical history, history of religion, Church and society, Christian culture, Christian ethics, bioethics, Church and contemporary challenges. ${ }^{39}$ However, the most important issue is whether religious teachers are properly incorporated into the school system and have a stable labor position or operate as part-time, temporary and transitory actors. The legal status of religious teachers, their position and duties in the schools from the point of labor law, remains one of the central factor in assessment of the RE model in every country.

2.5. Proper combination of the four elements can facilitate shaping of the best theoretical and practical RE pattern in public schools. Of course, there is a variety of combinations that can help different societies adapt their RE model to specific societal needs. In any case, those four attributes, together with some other less important features, are essential in profiling RE in legal systems and affect overall impression of the statechurch relations in different countries. Type of religious instruction is in a way a kind of litmus paper for revealing the political setting, attitude towards the religion, degree of cooperation and confidence between the state, churches and religious communities, relationship towards fundamental human rights and many other important characteristics of the state.

\section{RETURN OF RELIGIOUS EDUCATION IN PUBLIC SCHOOLS IN SERBIA - PRESENT SITUATION}

In every jurisdiction four mentioned elements of RE create more or less specific combination. Considering those criteria, RE in public schools in Serbia is state-paid only for the seven traditional Churches and religious communities. Religious instruction is a mandatory optional subject with alternative (Civic education). RE is mostly confessional, multi-de-

39 Orthodox Catechesis as Mandatory Optional Subject in Primary and Secondary Schools - Evaluation of the Programs and Teacher's Competences, Institute for Evaluation of Education Quality, Belgrade 2013, 13-17 [in Serbian]. 
nominational, both in elementary and in secondary schools. ${ }^{40}$ It is carried by religious teachers who are elected in coordination of the state and representatives of seven religious authorities, but they do not have a permanent position in the schools.

Religious instruction was firstly introduced in public schools quite carefully, by virtue of a governmental decree (not by law). It was the Decree on organization and realization of religious instruction and an alternative subject in the elementary and high schools issued in July $2001 .^{41}$ The Decree was used as an interim legislation to enable religious instruction in public schools to start already during the 2001/2002 school year. It was provided for members of seven traditional Churches and religious communities, relating to the first-year primary school pupils and the first year in high schools, but as an elective subject. ${ }^{42}$

The second step followed already in 2002, and that model of religious instruction is more or less effective up to the present time. The change was performed by Amending laws on the elementary and high schools. ${ }^{43}$ Important innovation was that religious instruction and alternative subject were not elective subjects like a year before. They became mandatory optional courses which are offered alternatively in the regular school curriculum. The parents (in elementary schools) or the pupil (in

40 Primary school in Serbia comprehends 8 classes (children from 7 to 14 years) and secondary school has 4 classes (14 to 18 years, after finishing primary education, non compulsory). Consequently there are three cycles of RE: the first one encompasses first four classes of elementary school, the second cycle is from $5^{\text {th }}$ to $8^{\text {th }}$ class of elementary school, and the third one is organized in four classes of grammar school.

41 Official Gazette of the Republic of Serbia, No. 46/2001 of July 27, 2001. According to the Decree, parents and other legally recognized representatives decide whether their children will attend Religious instruction in primary school or not. Pupils in secondary schools (starting with the age of 14 or 15) decide for themselves on enrolment of Religious instruction. Alternative subject was defined as "Civic education". Pupils may also opt out all together. Pupils were given only a descriptive mark that does not affect their final grade point average.

42 Interestingly, that Decree was the first legislative document which mentioned term "traditional churches and religious communities" and which defined seven of them in Art. 1, Clause 2 (Serbian Orthodox Church, Roman Catholic Church, Slovak Evangelical Church, Reformed Christian Church, Evangelical Christian Church, Islamic Community, and Jewish Community). The concept of "traditional churches and religious communities" became latter the chief notion, having been used in all subsequent legislations dealing with religious freedom, including the actual Law on Churches and Religious Communities enacted in April 2006 (Official Gazette of the Republic of Serbia, No. 36/2006 of April 28, 2006). The Law itself has only a short provision concerning religious instruction (Art. 8: "The right to religious instruction in state and private primary and secondary schools is guaranteed in accordance with law").

43 Law on amending the Law on Primary School (Official Gazette of the Republic of Serbia, No. 22/2002 of April 26, 2002) and Law on amending the Law on Secondary (High) School (Official Gazette of the Republic of Serbia, No. 23/2002 of May 9, 2002). 
secondary schools) have to opt for one subject or the other another. ${ }^{44}$ Usually, in every generation, a bit more than a half of pupils opt for religious instruction while others prefer Civic education. ${ }^{45}$ Attendance is mandatory for the given school year. Classes of religious instruction and civic education are scheduled once per week (36 classes per school year). Pupils are graded only with a descriptive mark that does not affect their final grade average

The minimum number of pupils which was required in Serbia for organization of RE in public school in the first years when religious instruction was introduced (2001) was only one pupil, according to the internal recommendation of the Ministry. It was technically impossible to realize such a concept consequently and it became an immense financial burden for the state. Therefore, according to the official Expert recommendation on structuring classes and financing elementary and secondary schools, which started to appear annually (the last was for 2015/16 school year), ${ }^{46}$ religious instruction has been organized in public schools if there has been a minimum of 15 interested pupils. During the last few years a number of schools have been allowed to enroll smaller groups than 15 pupils (but not less than 5). It was rather a tacit consensus than a normative solution.

The state and religious institutions cooperate closely within the mixed Commission for Organization and Realization of Religious Instruction (hereinafter: the Commission). ${ }^{47}$ It had first been formed by virtue of the mentioned Decree on organization and realization of religious in-

44 During the following years only a few changes were introduced, the most important being that pupils could choose alternative subject for one school year (instead for the whole cycle of four years). Consequently they may switch from one to another and combine the subjects. It established mobility and enabled pupils to get some knowledge in both fields of study.

45 Civic education has a hidden privilege in attracting more pupils. In the first four classes of primary school parents often pragmatically decide to opt for Civic education as it is taught by the class teacher (who is in charge of other subjects). On the contrary, RE is taught by a person who is not a regular member of the school staff and has only an annual contract. Similarly, at the high school level, some pupils opt for Civic education having pragmatically in mind a better relationship and communication that they can make with professors of philosophy, sociology, psychology, history or other subjects, who teach Civic education parallel with their major subjects. There are no teachers specialized in Civic education only, and teachers of other subjects who teach Civic education had passed through a particular training in that subject.

46 Expert recommendation on structuring classes and financing elementary and secondary schools, No. 110-00-181/2015-07 of July 14, 2015 issued by the Ministry of education.

47 Similar joint commission of the state and Lutheran Church exists for example in Estonia, but it is formed to discuss many issues (not only religious education), and it does not encompass other churches and religious communities like in Serbia. More in P. Valk, 167. 
struction and of an alternative subject in elementary and high schools of 2001. Its position was finally fixed in the Laws on Primary and Secondary (High) schools in 2013. ${ }^{48}$ The Commission is the primary body tasked to follow up and manage organization of religious instruction. It consists of six representatives of the state (in the first three years those were, among others, the Minister of Education and the Minister of Religion in person) and representatives of all seven traditional churches and religious communities (at the level of bishops, of the rabbi and of the muftis), who are elected by the Government for the six years term. The Commission's competences included revision and approval of all syllabi and textbooks prepared by churches and religious communities. ${ }^{49}$ The Minister of education adopts syllabi for Religious instruction upon unanimous proposal of churches and religious communities. Not a single syllabus of a religious instruction course could have been followed, nor a textbook published and circulated, without consent of all six other churches and religious communities, as well as of the state representatives. Also, religious institutions make the list of teachers, but the Commission has a final say in adopting it and consequently in selection of religious instructors. In that way full consensus in respect of the content and other important elements of religious instruction in the country has to be achieved. There is no privilege for the predominant Serbian Orthodox Church in that respect.

Evaluation of pupils in RE has remained descriptive and does not affect the final average grade. Classes are held once a week (36 hours per year). Religious teachers get a part-time job based upon an annual contract with the schools. Although the contact is usually renewed every year, it discriminates them in relation to other teachers in the schools, as well as in their labor law status and social benefits (credit restrictions, maternity leave, etc.). In this moment there are approximately 1.900 religious instructors in the country (over 1.600 Orthodox, over 150 Catholic, about 130 Muslim, etc.). Teachers are priests or laypersons who regularly posses certain university degree or "higher school" (college) level of education in religion, as some churches developed their own Institutes for Catechism. Fifteen years ago, in the beginning of RE introduction, qualification and competency of religious teachers was a serious problem. Currently they are mostly graduates from the Faculty of Theology or the

48 Art. 33 of the Law on Primary Education and Upbringing (Official Gazette of the Republic of Serbia, No. 55/2013) and Art. 7-8 of the Law on Secondary (High) Education and Upbringing (Official Gazette of the Republic of Serbia, No. 55/2013).

49 Law on Primary Education of 2013, Art. 33, Clause 8: "The Commission is particularly entitled for the issues of harmonization of syllabi for religious instructions, in adopting manuals in religious instructions, in adopting the list of teachers and other issues connected to organization of religious instruction". Similar provisions are prescribed in the Law on Secondary (High) Education of 2013 in Art. 7 and 8. 
catechetic institutions. Some of them graduated psychology, history of arts, political sciences, law, even military academy, and became teachers of religion after a particular preparation organized by the state and Churches. Not a small number have now master degree, while in this moment four religious teachers hold posses $\mathrm{PhD}$ degree. Majority of religious teachers are today laypersons, women and young people. In undeveloped areas and smaller places religious instruction is usually provided by the priests or some less competent persons, but generally speaking, an important step forward has been made in the religious teachers' competences.

Important development considering content of RE took place in June 2009. The agreement was reached between the representatives of seven traditional Churches and religious communities with the Ministry of Education on the curricula in the final grades of elementary and grammar (high) schools. In line with the Toledo Guiding Principles, but also due to genuine internal inputs, it was agreed that starting with the 2009/2010 school-year some cognitive and value oriented, not strictly religious elements have to became a part of the curriculum in the final class of the secondary school. ${ }^{50}$

The latest changes in Serbia have happened quite recently. Just in time when this text was about to be finished, a new RE curricula was adopted. The preparation lasted about two years and was handled by the Commission. The drafting team included several dozens of prominent religious teachers from all seven churches and religious communities. The result is modernized curricula with recognizable elements of teaching about religion and teaching from religion and value oriented approach, but again mostly in the final class of the secondary schools. ${ }^{51}$ In that way the first more serious step in developing rather cognitive religious teaching in Serbia has been made.

Together with those more or less common features of RE similar to many countries, there are some quite peculiar features in Serbian legislation on religious instruction.

3.1. The first is legal ground applied to delineate seven traditional churches and religious communities to qualify them for state paid RE in public schools. It is neither long historical presence nor number of followers (often used in some legislation for justification of the selection).

50 The syllabus of the fourth class of secondary schools since 2009 includes topics such as Christian comprehension of history; Liberty and Christianity; Egoism; Problems of Bioethics; Individual, family and social morality; Delinquency; Peer violence, etc.

51 Official Gazette of the Republic of Serbia - Educational Official Gazette, No. 11/2016 of August 27, 2016. The curriculum encompasses a wider topic "Christianity in the modern world", and treats issues such as egoism, bioethics, diseases, individual, family and social morality, consumer society, violence, theodicy, etc. 
The ground for that privilege in Serbia has been explained as rather legalistic, more objective and less vague. Namely, restitution (restoration) of $\mathrm{RE}$ belongs only to churches and religious communities which have had the right to state-paid religious instruction in public schools according to particular laws regulating their position before the World War II. ${ }^{52}$ This right was abolished by communist authorities (similarly as private property was nationalized) and RE was returned in the school system following property rights' principle of restitution. Legislative continuity and historical legal identity are usual explanations of that quite distinctive solution in comparative legislation.

3.2. Harmonization of attitudes and full consensus of the state and all traditional churches and religious communities among themselves is needed to achieve any decision about the content, syllabi, manuals, and selection of RE teachers. Role of the mixed Commission for religious instruction is quite distinctive in comparative legislations. In that way Serbia's multi-religious identity is strongly reflected and confirmed through RE.

3.3. Civic education as a subject which is an alternative to RE in the mandatory elective system is also not so frequent in other countries. Usual options are Ethics or Moral (with variations in the title). Having in mind that communist heritage has not affected only lack of religious feelings and knowledge, but also incomplete comprehension of human rights, it is necessary to offer to pupils more profound understanding of civil liberties and values. Both subjects have a similar goal - to foster tolerance, to increase pupil's capability for dialogue, to advance understanding of family members, friends, neighbors, and other people and have respect for their rights and convictions, to develop proper relationship between personal identity and otherness, etc. Possibility to change the elective subject every school year contributes to pupils' mobility and enable them to combine contents of the two approaches.

3.4. Very careful steps have been made towards non-confessional contents. It occurs in curricula of the last classes of secondary school but it also becomes less formally a part of religious instruction teaching.

52 The same logic was followed in the Law on Churches and Religious Communities of 2006. It firstly defines traditional churches and religious communities in Art. 10 (Traditional Churches are those which have had a historical continuity within Serbia for many centuries and which have acquired the status of a legal person in accordance with particular acts, that is: the Serbian Orthodox Church, the Roman Catholic Church, the Slovak Evangelical Church (a.c.), the Christian Reformed Church and the Evangelical Christian Church (a.c.), the Islamic Religious Community and the Jewish Religious Community). Then articles 11-15 refer to separate laws or other documents that granted the status of religious institutions before the World War II. 
Quick and aggressive shift in changing existing RE models could be counterproductive. Serbian experience shows that RE should evolve gradually, rather than radically.

3.5. Tendency to form new profile of educators in religion came out of necessity and it has shown good results. Religious teachers are not only theologians but also those who graduated psychology, philosophy, philology, history of arts, political sciences, law, etc. Contrary to previous habit to have mostly priests as teachers of RE in the public schools, the way towards more diversified intellectual background of teachers affects internal changes and modifications within the subject in each particular case.

3.6. Part time annual contract of RE teachers raises the level of their responsibility for an appropriate, multi-confessional and tolerant, fair and balanced approach to all religions and stimulates them to avoid religious extremism and radicalism. Knowing that their position depends every year on consensus of representatives of the seven religions and of the state, teachers avoid approach which could bring them reputation of religious activist who indoctrinates pupils. Consensus of the churches, religious communities and the state about the list of teachers has as a consequence risk for religious teachers to be replaced quite easily.

Further improvement of RE in Serbia should aim:

a) to perform additional improvements of syllabi, including more elements of cognitive and value approach, although confessional substance could not be abandoned;

b) to prepare new modern and high-quality manuals of religious instruction with a variety of contents in order to acquire better understanding of other religions;

c) to organize adequate trainings of religious instruction teachers in order to prepare them properly for the necessary innovations;

d) to ensure more stable legal position of religious teachers, to enable their devotion to more liberal pedagogical approach, not mostly being based on syllabi and formal set up;

e) to establish fair choice in opting for RE or Civic education, without a factual privilege of the latter, as parents/pupils often opt for it having in mind that regular teachers of other subjects teach Civic education in the same time;

f) to introduce more steady inspection (supervising) by the Commission, similarly as in some other countries such as Netherlands, Austria, etc., in order to evaluate how the goals are per- 
formed, particularly if there are doubts that some religious instruction classes are abused;

g) to enhance competences of the Commission as a constructive safeguard of inter-religious balance, equality and mutual understanding, both between churches and religious communities on the one hand, and the state on the other. Due to its composition and decision making processes, the Commission could guarantee valid fruitful co-operation and become spiritus movens of the changes towards reasonable future development of religious instruction in public schools in Serbia.

\section{RELIGIOUS IDENTITY V. ATHEISTIC HERITAGE}

The majority of parents in Serbia are unable to offer proper knowledge about their own religion due to their long-lasting communist alienation from the religion. Generations of parents received systematic atheist education at schools and religious illiteracy is immense. Many parents are still quite ignorant in their own faith, as well as in religious issues in general, even when they label themselves as believers. Children thereforequite quite rarely acquire appropriate education in religion from their parents or carers. The role of educators in religion has very often been undertaken by generations of grandparents, most frequently by grandmothers. Having been faced with that background, RE in public schools in Serbia was mainly oriented to the confessional approach, aiming to provide information to the pupils about their own religion, to instruct them in proper manners during the liturgy and inform them about importance of active and accurate participation in religious ceremonies, to encourage them to perceive, recognize and understand religious assessments together with other cultural, ethical and societal values. It is very important if young people acquire adequate information and attitudes from professional educators rather than by quite ignorant parents. Considering mostly atheist and agnostic heritage, after more than half a century, proper approach through RE in state-run schools is crucial in forming suitable and tolerant religious identity of the young generation. In conformity with religious diversity in the country, RE in public schools aims to secure formation of adequate religious identity not only for the majority Orthodox denomination (often closely connected with national identity), but it strongly respects plurality of religions and their differences. With the state paid religious instruction in public schools about $95 \%$ of believers in the country are given opportunity to obtain a professional and appropriate RE for their children. ${ }^{53}$

53 According to the last census of 2011 believers encompass about $95 \%$ of the population $-85 \%$ Orthodox Christians and about $10 \%$ of other denominations, see $n$. 4 . 
Due to long ignorance of religion during the communist era, religious identity of an average citizen is mostly intuitive, perceptive, historical, inherited and basically formal, as a kind of "collective ideal". ${ }^{54}$ Religious identity of about $85 \%$ of the Serbian population with Orthodox background is often based upon the religious tradition, ethnicity and culture. In every day's life religious feelings are manifested mainly sporadically: by celebrating once a year specific Orthodox family feast "Slava" (a peculiar Serbian St. patron's, holly protector's day), by observing Christmas and Easter rituals (now mostly followed by formal exchange of standardized SMS greetings), by church marriages, baptizing ceremonies, religious funerals, and quite rarely by regular attendance to the masses in the churches. ${ }^{55}$ However, important distinction exists between formal, external manifestation of religiosity on one side and internal, subjective attitude, on the other, which is not so easy to be discovered through statistic empiric polls. ${ }^{56}$ But, both types of religiosity are in Serbia mostly followed with a poor knowledge of religion in spite of vivid revival of religiosity after the fall of communism. ${ }^{57}$ Religious illiteracy is still huge. Nevertheless, religious feelings are quite strong and gladly manifested.

54 Durkheim similarly asserts that religion expresses a "collective ideal" which is the result of "the school of collective life that the individual has learned to idealize", E. Durkheim, The Elementary Forms of Religious Life, Oxford 2001, 318. And he adds that "it is an arbitrary simplification to see only the idealistic side of religion - in its way, it is realistic". This is why Z. Kuburic, D. Gavrilovic, "Verovanje i pripadanje u savremenoj Srbiji" [Believing and Belonging in Contemporary Serbia], Religija i tolerancija 10, 18/2012, 19 rightly differ traditional and personal religiosity.

55 Z. Kuburic, "Serbian Orthodox Church in the Context of the State's History", Religija i tolerancija 12, 22/2014, 394-395; P. Simic, "Srbija i Evropska unija: izmedju nacionalnog i evropskog identiteta", Religioznost građana Srbije i njihov odnos prema procesu evropskih integracija, ["Serbia and EU: between national and European identity", in: Religiosity of Serbian Citizens and their Relation towards European Integrations], (ed. J. Jablanov Maksimovic), Beograd 2011, 15-16. He mostly resumes results of the research performed in 2010 (see n. 57), stressing that although $93 \%$ of citizens decleare as believers only about one third $(27,8 \%)$ consider themselves as convicted believers accepting the teaching of their faith, $16,4 \%$ do not accept completelly the faith teaching, 39,1\% participate in the religious rites but are not active in their religious community. About $90 \%$ are practicing traditional religious rites like baptising, Slava, religious funerals, etc. but $51,9 \%$ go to church only few times during the year and about one fourth of population pray few times in year.

56 Valuable methodological contribution on religiosity research is offered by M. Blagojevic, "Aktuelna religioznost gradjana Srbije" [Actual Religiosity of the Serbian Citizens"], in: Religioznost u Srbiji 2010 [Religiosity in Serbia in 2010], (ed. A. Mladenovic), Belgrade 2010, 43-71.

57 The only recent research in that field is Religioznost u Srbiji 2010 [Religiosity in Serbia in 2010], (ed. A. Mladenovic), Belgrade 2010. Particularly instructive in that volume is article by M. Nikolic, A. Jovic-Lazic, "Religiozna tranzicija i/ili tranzicija religioznosti u Srbiji" [Religious Transition and/or Transition of Religiosity in Serbia"], 113121. They point that "collectivistic religiosity" is characteristic of all dominant denomination - Orthodox, Catholic and Muslim and define this attitude as "laic-cursory" religious 
In those circumstances young people usually accept the model of their parent's religious behavior without proper understanding of their own religion in depth. ${ }^{58}$ When parents have poor knowledge in religion, if they incline towards simplified, distorted, extreme or other kind of nonproper religious perceptions, it is quite likely that their children will follow the parents' path. If the influence of parents is insufficient or incorrect due to lack of adequate awareness of their own religion, and particularly if the parents have a priori prejudices towards other religions, it might result in dangerous consequences when religious identity of the child is formed in the primary group only. ${ }^{59}$ In countries whose generations of parents are quite ignorant in their own religion, the role of RE in schools becomes more important in forming appropriate religiousness.

Religious instruction in public schools in Serbia has therefore accomplished an important role during the last ten years since it was introduced ${ }^{60}$ It contributed in developing more knowledgeable and substantial acceptance of one's own religion and in shaping of more mature religious identity. It may take a decade more to fill the gap that existed in serious understanding of religions, but it could result in shaping more objective and valuable religious identity of the coming generations and could promote approach to other religions without animosities and prejudices. ${ }^{61}$ The next step should be expansion of RE profiled as cognitive and nonconfessional subject. It could cultivate in the long run more cognitive, intellectual, substantial religious identity, including awareness of importance of all religions in the lives of individuals and of the society. ${ }^{62}$

feelings. General conclusion is that religiosity in Serbia has rather formal character, based upon a need to fulfill the duty.

58 The influence of religion on identity formation often works through parental influence. Children whose parents are significantly religious are more likely to be significantly religious themselves, S. H. Oppong, "Religion and Identity", American international Journal of Contemporary Research, 3, 6/2013, 15.

59 Issue of individual religious identity of the child could be more complicated when parents do not belong to the same religion. More on that in interesting study of $\mathrm{E}$. Arweck, E. Nesbitt, "Young people's identity formation in mixed-faith families: continuity or discontinuity of religious traditions?", Journal of Contemporary Religion 25/2010, $67-87$.

60 Z. Kuburic, "Verska nastava u Srbiji - deset godina posle vracanja u obrazovni sistem" [RE in Serbia - ten years after its return in educational system], in: A. Mladenovic, 98 claims that RE enabled greater openness, more positive attitude towards religion and increasing interest in other religions.

61 In a recent PhD thesis defended at the University of Novi Sad Faculty of Philosophy (Dpt. of Pedagogy) the author's general conclusion is that RE contributes to the overall morality of the pupils, their self respect and esteem of the others and otherness, N. Kacaric, Doprinos verske nastave moralnosti mladih [Contribution of Religious Education to the Morality of Youngsters], Novi Sad 2016.

62 My classification into intuitive and cognitive religious identity corresponds in some way to Simon Coleman's and Peter Collins' attitude that each identity theory fits 
Consequently, in this moment in Serbia it is reasonable to affirm and stabilize teaching into religion. But it does not mean that it is impossible to educate pupils in the same time, at least partially, about other religions, as Hull would put it. ${ }^{63}$ Those two goals are not opposing and they could meet with each other in RE organized as mostly confessional subject. It is easy to achieve that aim by comparison, stressing the similarities and fostering positive approach to other religions. This is the process that Williaime has recognized as convergence in RE in Europe. It mostly happens through internal development within the confessional courses of religious instruction. ${ }^{64}$ The convergence of the content should not be necessarily prescribed in the formal RE curricula. During the classes of inspiring, good and responsible teachers critical topics appear spontaneously, often imposed by pupil's interaction. Quality and objectivity of religious teachers is essential in that process, as they could foster critical thinking and positive approach towards other religions. Religious teachers perform vital societal task, as adolescence is the period when identities, including religious identity, are mostly formed. The manner how religious identity is shaped, in hostile way towards others or on the path of understanding and cultivating religious solidarity, may affect behavior of the person during all his life. ${ }^{65}$

Surely, it does not mean that RE alone can decisively affect proper development of religious identity of the young people. Many other factors are involved in the process of personality building. Also, religious upbringing and education of the child is highly dependent on how well goals and curricula demands are implemented in practice. If organized or realized in fanatic, extreme or exclusive way (whether conceptually or due to deficiencies in organization and realization), religious instruction

into one of two classifications: primordial (where continuity is central) or situationalist (identity is contextual), Religion, Identity, and Change: Perspectives on Global Transformations (eds. Simon Coleman, Peter Collins) Aldershot 2004, 4. The former (primordial) is essentially the view of identity that suggests historical continuity. The primordial view of identity may entail continuity between community and individual, past and present. Following Coleman-Collins view, Powell describes those two types of religious identities. Primordial is the sort of identity intended by those pushing for recognition of a certain ethnicity or nationality; uniformity/homogeneity is paramount. Instead, religious identity may transform over time, receive fresh articulation given new situations, or may struggle with or against alternative identities throughout the daily life of the actor, A. J. Powell, "The Ideal - One Possibility for the Future of Religious Identity", Intermountain West Journal of Religious Studies, 6, 1/2015, 113-115.

63 J. Hull, "The contribution of religious education to religious freedom", in: Committed to Europe's Future: Contributions from Education and Religious Education (eds. H. Spinder, J. Taylor, W. Westerman), Münster 2002, 107-110.

64 J-P. Willaime, (2007b), 65.

65 More on that in C. McNamara Barry, L. Nelson, S. Davarya, Sh. Urry, "Religiosity and spirituality during the transition to adulthood", International Journal of Behavioral Development, 34/2010, 311-324. 
may grow to be harmful. But when it is properly conceptualized and controlled, as in the great majority of European countries, it can definitely mean a positive step forward in religious identity building, particularly in ex-communist countries. In the states whose official ideology was until recently that the "religion is opiate for the masses", when systematic and professional education in religion was lacking for many decades, presence of RE in public schools is indispensable. It is not a risk but an opportunity for the state and society, depending on how RE is be organized and controlled. When it implements tolerance, understanding, respect for others and their beliefs, leading to the education for democratic citizen, RE could turn out to be an important tool in making a better society.

Due to variety of elements and criteria in RE organization (concerning financing, content, degree of compulsoriness, status of religious teachers), it is possible to profile it to the best of the country's convenience and in accordance with its religious demography, historical, social, political, ethnic, and other peculiarities. Combination of different criteria could enable every legislation to find their own model which will develop proper balance and proper understanding of one's own religion and respect for other faiths. RE in public schools, which is supervised by the state and religious institutions jointly, whether confessional or non-confessional, mostly confessional or mostly cognitive, contributes to appropriate upbringing of religious identity of the young generation and affects their future valid perception of citizenship in a pluralist society.

Shaping of religious identity through RE is certainly not the same as citizen formation, although there are possibilities to link these two fields further, ${ }^{66}$ but not through formal education programmes by merging school subjects. Also, countries with different history and heritage should not be under any preasure to organize RE in a similar way. Traditions of the Netherlands and Russia, for example, are so diverse that it is would be wrong to approach to RE in state-run schools with the identical models. Countries with long atheistic (often anti-theistic) historical background are obliged to enable building of proper religious identity of the youth, and then to make a step forword. Any combination of educating about and from religion, as Jackson is so much in favor, is a very good answer for European countries which experienced continuity in relationship between the state and religion, ${ }^{67}$ but not necessarily for countries with different traditions.

66 S. Miedema, "Context, Debates and Perspectives of Religion in Education in Europe", Religion and Education in Europe (eds. Robert Jackson et allia), Münster -New York - München - Berlin 2007, 268.

67 Educating from religion "involves pupils in considering different responses to religious and moral issues, so that they may develop their own views in reflective way, to develop their own point of view on matters relating to religion and values", R. Jackson, "European Institutions and the Contribution of Studies of Religious Diversity", Religion 


\section{CONCLUSION}

Having in mind importance of religious identity formation and its impact to overall society there is always a need to improve RE system. Most European countries are continually exploring the model which could best fit historical, ethnic, political, social environment and other important factors. The tendency to shift from confessional religious instruction towards a cognitive model, the way from teaching into religion to teaching about religion, is perceived as a kind of convergence process in many European countries. Religious unstruction is an issue and a matter of debate not only in post-communist countries. It is still arguable how quickly the changes should be introduced, how radical the shift should be, and most importantly, how far should it go in deserting the prevailing denominational model of RE in public schools.

Religious instruction in Serbia is mostly confessional in this moment but it has interesting and useful peculiarities from comparative point of view. In order to improve quality of religious instruction in Serbian educational system, to shape formation of proper religious identity as a part of overall civic identity, two needs are contending - to keep teaching pupils in their own religion and to accustom them with values of other religions. Immediate transformation to a multi-religious subject, merging with civic education as proposed by the former Minister of education, or introducing a similar kind of patchwork subject, would rather be a risky experiment than a useful change. Having in mind present context it would be a great step forward if education into religion steadily acquires elements of education about religion, inspired with the idea of education from religion. Transformation towards mostly confessional religious instruction by introducing more cognitive and value oriented elements is maybe not completely satisfactory and quick enough. But it looks like the most realistic scenario for the present societal and political circumstances in Serbia and many other ex-communist countries. Gradual changes approach is not only necessary, but the only promising successful way of RE transformation into a valuable school subject which will make contribution to development of appropriate religious identity of the young people, fostering of religious tolerance, mutual understanding, and prevention of all kinds of religious extremism.

and Education in Europe (eds. R. Jackson et allia), Münster - New York - München Berlin 2007, 29. 


\section{REFERENCES}

Aleksandar Prascevic, A., "The Process of Religious Education in Public Schools of Republic of Serbia 2001-2011", http://www.pravoslavie.ru/english/51724.htm.

Aleksov, B., "Religious Education in Serbia", Religion, State \& Society, $4 / 32,2004$

Arweck, E., Elenaor Nesbitt, E., "Young people's identity formation in mixed-faith families: continuity or discontinuity of religious traditions?", Journal of Contemporary Religion, 25/2010.

Avramovic, S., "Church and State in Serbia", in: Law and Religion in Post-Communist Europe (eds. Silvio Ferrari, W. Cole Durham), Leuven-Paris-Dudley, MA 2003.

Avramovic, S., "Pravo na versku nastavu u našem i uporednom pravu", Anali Pravnog fakulteta u Beogadu ("Right to religious instruction in our and comparative law", Annals of the Faculty of Law in Belgrade), $1 / 2005$.

Avramovic, S., "Right to Religious Instruction in Public Schools", Annals of the Faculty of Law in Belgrade 3/2006.

Avramovic, S., "Serbia", in: Religion and the Secular State: National Reports (eds. W. C. Durham, J. Martinez-Torron), Madrid 2015.

Avramovic, S., "Ustavnost verske nastave u državnim školama - res iudicata", Anali Pravnog fakulteta u Beogradu ("Constitutionality of religious instruction in public schools - res iudicata", Annals of the Faculty of Law in Belgrade), 2/2006.

Blagojevic, M., "Aktuelna religioznost gradjana Srbije" (Actual Religiosity of the Serbian Citizens"), in: Religioznost u Srbiji 2010 (Religiosity in Serbia in 2010), (ed. Andrijana Mladenovic), Belgrade 2010.

Coleman, S., Collins, P., Religion, Identity, and Change: Perspectives on Global Transformations (eds. Simon Coleman, Peter Collins) Aldershot 2004.

Draskic, M., "Pravo deteta na slobodu veroispovesti u skoli", Anali Pravnog fakulteta u Beogradu ("Right of children to religious freedom in schools", Annals of the Faculty of Law in Belgrade), 1-4/2001.

Draskic, M., "O veronauci u državnim školama, drugi put", Anali Pravnog Fakulteta u Beogradu ("On religious instruction in public schools, the second time", Annals of the Faculty of Law in Belgrade), $1 / 2006$.

Durkheim, E., The Elementary Forms of Religious Life, Oxford 2001. 
Ferrari, A., "La religion dans l'éducation publique - le cas Italien", in: Religion in Public Education - La religion dans l'éducation publique (ed. Gerhard Robbers), Trier 2011.

Ferrari, S., "L'enseignement des religions en Europe: un aperçu juridique", in: Des maîtres et des dieux. Ecoles et religions en Europe (eds. J-P. Willaime, S. Mathieau), Paris - Berlin 2005.

Ferrari, S., "Religious education in the European Union", in: The Routledge International Handbook of Religious Education (eds. Derek H. Davis, Elena Miroshnikova), London - New York 2013.

Folque, A., "Religion in Public Portuguese Education", in: Religion in Public Education - La religion dans l'éducation publique (ed. Gerhard Robbers), Trier 2011.

Hammer, S., Franck, J., "Religion in Public Education - Report on Austria", in: Religion in Public Education - La religion dans l'éducation publique (ed. Gerhard Robbers), Trier 2011.

Hasenclever, A., "Geteilte Werte - Gemeinsamer Frieden? Überlegungen zu zivilisierenden Kraft von Religionen und Glaubensgemeinschaften", in: Friedenspolitik: Etische Grundlagen internationaler Beziehungen (eds. H. Küng, D. Senghaas), München 2003.

Hull, J., "The contribution of religious education to religious freedom", in: Committed to Europe's Future: Contributions from Education and Religious Education (eds. H. Spinder, J. Taylor, W. Westerman), Münster 2002.

Institute for Evaluation of Education Quality, Orthodox Catechesis as Mandatory Optional Subject in Primary and Secondary Schools Evaluation of the Programs and Teacher's Competence", Belgrade 2013.

Ivanc, B., "Religion in Public Education - Slovenia", in: Religion in Public Education - La religion dans l'éducation publique (ed. Gerhard Robbers), Trier 2011.

Jackson, R., "European Institutions and the Contribution of Studies of Religious Diversity", in: Religion and Education in Europe (eds. Robert Jackson et allia), Münster - New York - München - Berlin 2007.

Jankovic, M. D., "Vracanje verske nastave u obrazovni sistem Srbije" [Return of Religious Instruction in Educational System of Serbia], Novi Sad 2015.

Kacaric, N., Doprinos verske nastave moralnosti mladih (Contribution of Religious Education to the Morality of Youngsters), Novi Sad 2016. 
Kaurin, D., Morgan, W. J., "Orthodoxy and Education in Post-Socialist Serbia, A Comment", Journal of Religion and Society, 15/2013.

Kozyrev, F., Fedorov, V., "Religion and Education in Russia, Historical Roots, Cultural Context and Recent Developments", in: Religion and Education in Europe (eds. Robert Jackson et allia), Münster - New York - München - Berlin 2007.

Kuburic, Z., "Serbian Orthodox Church in the Context of the State's History", Religija i tolerancija 12, 22/2014.

Kuburic, Z., "Verska nastava u Srbiji - deset godina posle vracanja u obrazovni sistem" (RE in Serbia - ten years after its return in educational system), in: Religioznost u Srbiji 2010 (Religiosity in Serbia in 2010), (ed. Andrijana Mladenovic), Belgrade 2010.

Kuburic, Z., Gavrilovic, D., "Verovanje i pripadanje u savremenoj Srbiji" (Believing and Belonging in Contemporary Serbia), Religija i tolerancija 10, 18/2012.

Kuburic, Z., Vukomanovic, M., "Religious education: the case of Serbia", Sociologija, 3, 47/2005.

Lisovskaya, E., "Religious Education in Russia: Inter-Faith Harmony or Neo-Imperial Toleration?", Cogitatio, Social Inclusion 4, 2/2016.

Llorent-Bedmar, V., Cobano-Delgado, V., "The Teaching of Religious Education in Public Schools in the Nordic Countries of Europe", Review of European Studies 6, 4/2014.

Loloçi, K., "Albania", in: Encyclopedia of Law and Religion, I-V (eds. Gerhard Robbers, W. Cole Durham), Leiden-Boston 2016.

Magioros, N. Ch., "Religion in Public Education - Report on Greece", in: Religion in Public Education - La religion dans l'éducation publique (ed. Gerhard Robbers), Trier 2011.

McNamara Barry, C., Nelson, L., Davarya, S., Urry, Sh., "Religiosity and spirituality during the transition to adulthood", International Journal of Behavioral Development, 34/2010.

Messner, F., "Religion et éducation en France", in: Religion in Public Education - La religion dans l'éducation publique (ed. Gerhard Robbers), Trier 2011.

Miedema, S., "Context, Debates and Perspectives of Religion in Education in Europe", in: Religion and Education in Europe (eds. Robert Jackson et allia), Münster - New York - München - Berlin 2007.

Nikolic, M., Jovic-Lazic, A., "Religiozna tranzicija i/ili tranzicija religioznosti u Srbiji" (Religious Transition and/or Transition of Religiosity in Serbia"), [Religiosity in Serbia in 2010], (ed. Andrijana Mladenovic), Belgrade 2010.

Oppong, S. H., "Religion and Identity", American international Journal of Contemporary Research, 3, 6/2013. 
Powell, A. J., "The Ideal - One Possibility for the Future of Religious Identity", Intermountain West Journal of Religious Studies, 6, $1 / 2015$.

Romanova, E. G., "Religious education in modern Russia", in: The Routledge International Handbook of Religious Education (eds. Derek H. Davis, Elena Miroshnikova), London - New York 2013.

Schanda, B., "Religious education in Hungary", in: The Routledge International Handbook of Religious Education (eds. Derek H. Davis, Elena Miroshnikova), London - New York 2013.

Schanda, B., Legislation on Church-State Relations in Hungary, Budapest 2002, 22-23. The Czech Republic has a similar system, Jiř́ Rajmund Tretera, Záboj Horák, "Religion in Public Education in the Czech Republic", in: Religion in Public Education - La religion dans l'éducation publique (ed. Gerhard Robbers), Trier 2011.

Schreiner, P., "Religious education in the European context", in: Crossings and Crosses: Borders, Educations, and Religions in Northern Europe (eds. Jenny Berglund, Thomas Lundén, Peter Strandbrink), Boston-Berlin 2015.

Schreiner, P., "Situation and Current Developments of Religious Education in Europe", in: Religious Education in a Plural, Secularised Society. A Paradigm Shift (eds. Leni Franken, Patrick Loobuyck), Münster-New York-München-Berlin 2011.

Simic, P., "Srbija i Evropska unija: izmedju nacionalnog i evropskog identiteta", Religioznost građana Srbije i njihov odnos prema procesu evropskih integracija, ["Serbia and EU: between national and European identity", in: Religiosity of Serbian Citizens and their Relation towards European Integrations], (ed. Jelena Jablanov Maksimovic), Beograd 2011.

Tăvală, E. P., "Religion and Public Education in Romania", in: Religion in Public Education - La religion dans l'éducation publique, (ed. Gerhard Robbers), Trier 2011.

Valk, P., "Religious Education in Estonia", Religion and Education in Europe (eds. Robert Jackson et allia), Münster - New York München - Berlin 2007.

Weisse, W., "The European Research Project on Rerligion and Education REDCo. An Introduction", in: Religion and Education in Europe (eds. R. Jackson et allia), Münster - New York - München - Berlin 2007.

Willaime, J. P., "Teaching Religious Issues in French Public Schools. From Abstentionist Laïcité to a Return of Religion to Public Education", in: Religion and Education in Europe (eds. Robert Jackson et allia), Münster - New York - München - Berlin 2007a. 
Willaime, J. P., "Different Models for Religion and Education in Europe", in: Religion and Education in Europe (eds. Robert Jackson et allia), Münster - New York - München - Berlin 2007b. 